\title{
INVESTIGATION OF THE PROPERTIES OF THE ORAL LIQUID AND POLYMORPHISM OF THE MUC5B GENE IN CHILDREN WITH CYSTIC FIBROSIS
}

\author{
Nazaryan R. ${ }^{1}$, Tkachenko M. ${ }^{1}$, Volkova $N_{.}{ }^{2}$ \\ ${ }^{1}$ Kharkiv National Medical University, Ukraine \\ ${ }^{2}$ V. N. Karazin Kharkiv National University, Ukraine \\ https://doi.org/10.35339/ic.7.1.33-37
}

\begin{abstract}
The article presents the study of biophysical and biochemical properties of saliva and polymorphism of the MUC5B protein gene in children with cystic fibrosis.

It has been determined that the development of chronic gingivitis in children with cystic fibrosis occurs secondary to an increase in saliva elasticity and a decrease in salivation rate. The presence of the MUC5B gene allele with 9 repeats (59 bp) in the intron 36 in the genotype for cystic fibrosis patients likely indicates a lower tendency to gingivitis, while the patients possessing the allele with 6 repeats in the genotype were found to have a higher percentage of moderate gingivitis. These data could be used to predict the development of chronic gingivitis, depending on the genetic polymorphism of the MUC5B gene and to form risk groups for differentiated prescription of preventive and therapeutic measures.
\end{abstract}

Key words: children, cystic fibrosis, gene polymorphism, gingivitis, oral fluid.

\section{Introduction}

To date, many studies have proven a significant prevalence of periodontal tissue diseases among children with a common disorder [1,2]. Cystic fibrosis (CF) is considered to be one of somatic diseases that have an effect on the course of diseases of the organs of the oral cavity.

$\mathrm{CF}$ is a genetic disease caused by mutation of the gene of the cystic fibrosis transmembrane conductance regulator (CFTR). There are three main links in the pathogenesis of $\mathrm{CF}$, namely an impaitment of exocrine glands function, a disruption of electrolyte metabolism and connective tissue damage. These processes condition a release of products with altered physical and chemical properties and the development of pathological changes mainly in the pulmonary, digestive, endocrine and reproductive systems. Diseases of bronchopulmonary organs (airway obstruction,

Corresponding Author:

M. Tkachenko MD, PhD, Associate Professor of the Pediatric Dentistry, Pediatric Maxillofacial Surgery and Implantology Department, Kharkiv National Medical University, Ukraine. E-mail:tmvv.13@gmail.com chronic rhinitis, nasal polyps and chronic colonization of the respiratory tract characteristic of the microflora) are the most characteristic manifestations of CF. Violations in the digestive system are manifested by pancreatic insufficiency, gastroesophageal reflux disease, liver disease, and intestinal disorders [3-6].

Secondary pathological changes in many organs also have an impact on the development of dental diseases. Submandibular salivary glands are known to be filled with eosinophilic substrates of high viscosity in patients with CF. The parotid and small salivary glands are not histologically altered, but they produce a secretion with an excess of sodium and chloride ions [7]. Moreover, it is associated with an increase in the concentration of free and bound calcium in the submandibular glands and the variation in the $\mathrm{pH}$, content of inorganic calcium and some enzymes in the oral fluid. Impaired salivation can result in nonspecific parotitis $[8,9]$. Properties of mixed saliva, which performs important functions of providing homeostasis, mineralization, protection and cleaning in the oral cavity, undergo considerable changes.

Diabetes is a concomitant disease in these patients. It is known that the early stages of the 
disease are characterized by hypersalivation with atrophic changes in parenchyma and hypofunction of glands at later periods $[10,11]$.

The content of mucins also determines the properties of oral fluid playing an important role in the protection against pathogens and in physiological microenvironment support for microorganisms [12]. It has been proved that MUC5B mucin production is increased in patients with CF [6]. There is scientific evidence that $R$. aeruginosa and $S$. aureus (infections comorbid with cystic fibrosis) activate cell membrane receptors and stimulate mucin secretion. At the same time, interaction of carbohydrate structures of mucin with these microorganisms results in deterioration of oral fluid quality [13]. Deviation from the normal parameters of the oral fluid contributes to the local pathological processes, such as dental caries and periodontal diseases [12]. Analysis of literature sources also revealed that allelic variants of the MUC5B gene could be assessed as markers of early diagnosis of predisposition to gingivitis [14-16].

Thus, the study of the effect of CF pathogenesis on the properties of oral fluid as one of gingivitis risk factors in children, as well as the search for possible genetic predictors to inflammatory periodontal diseases is of particular scientific interest.

2. Purposes, subjects and methods:

2.1. The purpose of the work was to evaluate mucin level, the level of oral fluid elasticity (viscosity), saliva flow rate and alleles of MUC5B protein gene CNV polymorphism in children with $\mathrm{CF}$, as well as to analyze the effect of determined parameters on the progress of chronic gingivitis in this cohort of patients.

\subsection{Subjects and Methods}

To achieve the goal, the study involved 30 children with a confirmed diagnosis of CF aged from 2 to 17 years (the main group). The comparison group included 23 children of similar age without somatic diseases.

The assessment of the periodontal condition was carried out using the PMA index (Parma, 1960), which reflects the degree of intensity of gum inflammation from "mild" to "severe".

The rate of the salivation was determined by the method of T. L. Redinova and A. R. Pozdeeva (1994). Graduated test tubes were used to collect unstimulated oral fluids.

Saliva elasticity was determined by the method of P. A. Leus and L.V. Belyasova (1995) which was conducted with the help of a dental pincer. The oral liquid was pulled out with thin threads, and the results were evaluated from "sharply positive" to "sharply negative".

Unstimulated saliva was collected from patients in sterile tubes in the amount of $2 \mathrm{ml}$ to study the level of mucin. The analysis was carried out in a laboratory using Benedict's reagent.

The structure of MUC5B gene involves 48 exons and 47 intrones. It contains a large central exon 30 (10713 bp) and a series of straight sequential repeats of $59 \mathrm{bp}$. (Sequence - cctgtgcggt gagtggggge ggcccegggc ccccagacc cctcggectc tctgagtgt) in intron 36 [17]. We chose this CNV polymorphism (the number of copies of indicated sequence) for the analysis.

For genotyping, buccal epithelial cells were used. DNA was isolated from these cells using the Diatom TM DNA Prep 100 commercial kit (Russian Federation). CNV polymorphism typing in the intron 36 of MUC5B gene was performed using a polymerase chain reaction (PCR) with the detection of amplified fragments in agarose gel [17]. The following primers were used for amplification: $\quad$ MUC5B F - 5'AGTGTGCAGTGACTGGCGAG-3' and MUC5B R - 5'-CTAGAGTTGCAGGTGGCAGG-3'. For PCR, an automatic thermal cycler "Terzik" (Russian Federation) and commercial reagent kits GenPak TM PCR Core (0.5 ml) (Russian Federation) were used. Fragment sizes were determined by comparison with the molecular weight marker pUC19 DNA / Mspl (HpaII) Marker (Thermo Fisher Scientific Inc.). All reagents and devices were used according to the manufacturer's instructions.

The results were statistically processed with the standard software Statistica 8.0 Microsoft Excel.

The institutional Committee in Ethics and Bioethics approved the investigation. Written consent from children's parents were obtained.

Conflict of interests. There is no conflict of interests.

\section{Results and discussion}

The average index of the PMA showed significant differences in the main and control groups: $47.98 \pm 3.47 \%$ and $9.17 \pm 2.29 \%$, respectively $(p<0.01)$. The estimation of the periodontal status revealed clinical signs of chronic generalized catarrhal gingivitis in all $(100 \%)$ children of the main group. Thus, 7 (23.3\%) children had a mild degree, $15(50 \%)$ children a moderate and 8 (26.7\%) children had a severe degree of chronic catarrhal generalized gingivitis.

Analysis of the studied parameters of oral fluid revealed a deterioration of these values and 
their difference in children with CF compared with the control group. Instead, the content of mucin in the oral fluid in children of both groups did not show a significant difference between the indicators (Table 1).

The study of correlation between periodontal indices and oral fluid properties also showed a difference in the studied groups. Thus, in the main
48 patients (Table 2). There were 15 different genotype variants in the control group and 16 in the main group. In both groups there were individuals homozygous for a specific allele (39\% and $40 \%$, respectively), heterozygous for two alleles (22\% and $28 \%$, respectively), as well heterozygous individuals possessing three different alleles (39\% and 32\%, respectively).

Indicators of properties of the oral fluid in the studied groups

\begin{tabular}{|l|c|c|}
\hline \multirow{2}{*}{ Indicator } & \multicolumn{2}{|c|}{ Total, $(\mathrm{M} \pm \mathrm{m})$} \\
\cline { 2 - 3 } & The main group & The control group \\
\hline Saliva rate, $\mathrm{ml} / \mathrm{min}$ & $0.19 \pm 0.01^{*}$ & $0.39 \pm 0.01^{*}$ \\
& $(\mathrm{n}=24)$ & $(\mathrm{n}=23)$ \\
\hline Elasticity of oral fluid, unit & $1.07 \pm 0.17^{*}$ & $-13 \pm 0.25^{*}$ \\
& $(\mathrm{n}=30)$ & $(\mathrm{n}=23)$ \\
\hline Mucin of oral fluid, $\mathrm{g} / \mathrm{l}$ & $2.16+0.06$ & $(\mathrm{n}=23)$ \\
\hline
\end{tabular}

Note: * the difference is statistically significant $(\mathrm{p}<0.01)$ between the groups.

group, the index of elasticity of oral fluid directly affected the value of the PMA index $(r=0.55$; $\mathrm{p}<0.01)$. This link in the comparison group was missing. Patients with CF were found to have a significant negative correlation between the rate of salivation and the elasticity of oral fluid $(\mathrm{R}=-0.67$; $\mathrm{p}<0.05$ ), and direct connection between the rate of salivation and the mucin content $(\mathrm{R}=0.53 ; \mathrm{p}<0.05)$.

Based on genotyping results alleles of the MUC5B gene polymorphism were established for
For the control group homozygous $2 / / 2$ (17.4\%), heterozygous $3 / / 5 / / 8(13 \%)$ and homozygous $8 / / 8$ (13\%) genotypes were more common. Some of these variants were also found in the case group: $3 / / 5 / / 8(12 \%)$ and $8 / / 8$ (12\%), but not $2 / / 2$ homozygous ones.

The analysis of the periodontal status using PMA index showed that only the carriers of 9 repeats allele in the case group significantly differed from those without such allele. The

The genetic diversity of the control and main groups by alleles

Table 2 of the CNV polymorphism in the MUC5B gene

\begin{tabular}{|c|c|c|c|c|c|}
\hline \multicolumn{3}{|c|}{ Control group } & \multicolumn{3}{|c|}{ Case group } \\
\hline Genotype & $(n)$ & $(\%)$ & Genotype & (n) & $(\%)$ \\
\hline $2 / / 2$ & 4 & 17.4 & $3 / / 5$ & 1 & 4.0 \\
\hline $2 / / 3$ & 1 & 4.3 & $3 / / 5 / / 8$ & 3 & 12.0 \\
\hline $2 / / 7$ & 1 & 4.3 & $3 / / 6$ & 1 & 4.0 \\
\hline $2 / / 7 / / 9$ & 1 & 4.3 & $3 / / 6 / / 8$ & 3 & 12.0 \\
\hline $3 / / 4 / / 7$ & 1 & 4.3 & $3 / / 6 / / 9$ & 1 & 4.0 \\
\hline $3 / / 5 / / 8$ & 3 & 13.0 & $3 / / 7 / / 8$ & 1 & 4.0 \\
\hline $3 / / 6 / / 8$ & 1 & 4.3 & $4 / / 4$ & 1 & 4.0 \\
\hline $4 / / 6 / / 7$ & 1 & 4.3 & $4 / / 7$ & 1 & 4.0 \\
\hline $5 / / 5$ & 1 & 4.3 & $5 / / 8$ & 1 & 4.0 \\
\hline $5 / / 7 / / 9$ & 1 & 4.3 & $5 / / 9$ & 1 & 4.0 \\
\hline $6 / / 6$ & 1 & 4.3 & $6 / / 6$ & 2 & 8.0 \\
\hline $6 / / 7 / / 8$ & 1 & 4.3 & $6 / / 8$ & 1 & 4.0 \\
\hline $6 / / 9$ & 2 & 8.7 & $6 / / 9$ & 1 & 4.0 \\
\hline $7 / / 9$ & 1 & 4.3 & $7 / / 7$ & 3 & 12.0 \\
\hline \multirow[t]{2}{*}{$8 / / 8$} & 3 & 13.0 & $8 / / 8$ & 3 & 12.0 \\
\hline & & & $9 / / 9$ & 1 & 4.0 \\
\hline \multicolumn{6}{|c|}{ Total } \\
\hline 15 & 23 & 100 & 16 & 25 & 100 \\
\hline
\end{tabular}


presence of 9 repeats allele in MUC5B gene in genotype ( $U=9.5, p<0.05$, Mann-Whitney test) in CF patients could indicate a lower tendency to chronic gingivitis. Among children with a moderate degree of gingivitis development prevailed $(U=22.0, p<0.05)$ the carriers of 6 repeats allele. At the same time, PMA index in both studied groups did not correlate with the total number of $59 \mathrm{bp}$ repeats in the intron 36 of MUC5B gene.

In the case group the analysis of linkages between the presence of some MUC5B allele in genotype and the index of saliva elasticity revealed some associations (Table 3), while none of them were proved statistically. We consider this fact reflects quite a small sample size of the main group. With a larger sample we expect to obtain allele carriers, i.e. almost all the carriers of this allele typically have low saliva elasticity and these patients have a lower level of gingivitis.

\section{Conclusions}

The development of chronic gingivitis in children with CF occurs secondary to an increase in saliva elasticity and a decrease in the rate of salivation.

In $\mathrm{CF}$ patients the presence of the allele of MUC5B gene with 9 repeats (59 bp) in the intron 36 in the genotype likely indicates a lower tendency to gingivitis, while patients possessing the allele with 6 repeats in the genotype were found to have a higher percentage of moderate gingivitis. These data can be used to predict the development of chronic gingivitis, depending on the genetic polymorphism of the MUC5B gene and to form

The results of analysis of linkages between the presence of some MUC5B allele in genotype and the index of saliva elasticity for cystic fibrosis patients (main group)

\begin{tabular}{|c|c|c|c|c|c|c|c|c|}
\hline $\begin{array}{c}\text { Allele } \\
\text { MUC5B }\end{array}$ & $\chi^{2}(p)$ & $\begin{array}{c}Q, \\
\text { coefficient } \\
\text { of association }\end{array}$ & $\begin{array}{c}Y, \\
\text { coefficient } \\
\text { of colligation }\end{array}$ & $\begin{array}{c}V, \\
\text { coefficient } \\
\text { of contingent }\end{array}$ & OR & $(C /)$ & Z stat. & $p$ \\
\hline 3 & $\begin{array}{c}0.01 \\
(>0.05)\end{array}$ & $0.04(<0.5)$ & 0.02 & 0.02 & 1.5 & $(0.27-8.45)$ & 0.46 & 0.65 \\
\hline 4 & $\begin{array}{c}1.17 \\
(>0.05)\end{array}$ & $-1(>0.5)$ & -1 & -0.23 & 0.32 & $(0.01-7.45)$ & 0.71 & 0.47 \\
\hline 5 & $\begin{array}{c}0.83 \\
(>0.05)\end{array}$ & $0.41(<0.5)$ & 0.22 & 0.19 & 2.4 & $(0.36-16.21)$ & 0.89 & 0.37 \\
\hline 6 & $\begin{array}{c}0.01 \\
(>0.05)\end{array}$ & $-0.05(<0.5)$ & -0.03 & -0.02 & 0.9 & $(0.15-5.26)$ & 0.12 & 0.91 \\
\hline 7 & $\begin{array}{c}0.49 \\
(>0.05)\end{array}$ & $0.37(<0.5)$ & 0.19 & 0.15 & 2.17 & $(0.24-19.28)$ & 0.69 & 0.49 \\
\hline 8 & $\begin{array}{c}1.81 \\
(>0.05)\end{array}$ & $\mathbf{- 0 . 5 4}(>\mathbf{0 . 5})$ & -0.29 & -0.28 & 0.3 & $(0.05-1.79)$ & 1.32 & 0.19 \\
\hline 9 & $\begin{array}{c}1.55 \\
(>0.05)\end{array}$ & $\mathbf{0 . 6 5}(>\mathbf{0 . 5})$ & 0.37 & 0.26 & 4.67 & $(0.35-61.83)$ & 1.17 & 0.24 \\
\hline
\end{tabular}

more significant indices. For now, we can admit the tendency to negative association between the presence of 4 repeats MUC5B allele in genotype and low saliva elasticity. Similar thing is shown for 8 repeats allele carriers. On the contrary, positive association is supposed to be for 9 repeats risk groups for differentiated prescription of preventive and therapeutic measures.

The presence of some MUC5B alleles in the genotype and index of saliva elasticity had some associations, but the relationship has not been proved statistically.

\section{References}

1. Kazakova R.V., Mel'nik V.S. (2013). Vza€mozv'yazok zapal'nih zahvoryuvan' parodonta i patologii organiv travlennya u ditej i pidlitkiv [Interconnection of inflammatory diseases of periodontal disease and pathology of digestive organs in children and adolescents]. Naukovij visnik Uzhgorods'kogo universitetu, 2 (47), $150-4$.

2. Gumenyuk M.I., Mazur I.P., Ignat'eva V.I., Harchenko-Sevryukova G.S. (2015). Osoblivosti klinichnih proyaviv patologichnih procesiv parodonta u hvorih na hronichne obstruktivne zahvoryuvannya legen' [Features of clinical manifestations of pathological processes of periodontis in patients with chronic obstructive pulmonary disease]. Ukraïns'kij pul'monologichnij zhurnal, 1,40-4. 
3. Grechanina E.YA., Grechanina YU.B., YAnovskaya A.A. (2014). ZHeludochno-kishechnye i metabolicheskie narusheniya pri mukoviscidoze [Gastrointestinal and metabolic disorders in cystic fibrosis]. Likar. Sprava,11,149-54.

4. Baranov A.A., editor (2009). Klinicheskie Rekomendacii. Pediatriya [Clinical Recommendations. Pediatrics]. Soyuz Pediatrov Rossii. 2-e izd. Moscow:GEHOTAR-Media, 432 p.

5. Klyarits'ka I.L., Moshko YU.A. (2010). Gastroenterologichni problemi mukoviscidozu [Gastroenterologic problems of cystic fibrosis]. Krims'kij terapevtichnij zhurnal, 2, 37-41.

6. Kapranov N.I., Kashirskaya N.YU., editors (2014). Mukoviscidoz [Cystic Fibrosis]. Moscow:ID "Medpraktika-M", 672 p.

7. Nakaz Ministerstva ohoroni zdorov'ya Ukraïni № 723 (15.07.2016) "Pro zatverdzhennya ta vprovadzhennya mediko-tekhnologichnih dokumentiv zi standartizaciï medichnoï dopomogi pri mukoviscidozi" [Order of the Ministry of Health of Ukraine No. 723 (15.07.2016) "On approval and implementation of medical-technological documents on standardization of medical aid in cystic fibrosis]. Retrieved : http://www.moz.gov.ua/ua/portal/dn 20160715 0723.html.

8. Orlov A.V., Simonova O.I., Roslavceva E.A., SHadrin D.I. (2014). Mukoviscidoz (klinicheskaya kartina, diagnostika, lechenie, reabilitaciya, dispanserizaciya): uchebnoe posobie dlya vrachej [Cystic fibrosis (clinical picture, diagnosis, treatment, rehabilitation, clinical examination): a training manual for doctors]. Sankt-Peterburg: Izd-vo SZGMU im. I. I. Mechnikova,160 p.: il.

9. Patel R.M., Varma S., Suragimath G., Zope S. (2016). Estimation and Comparison of Salivary Calcium, Phosphorous, Alkaline Phosphatase and pH Levels in Periodontal Health and Disease: A Crosssectional Biochemical Study. J Clin Diagn Res, 10(7), 58-61.

10. Alexander S. (2014). Clinical Guidelines: Care of Children with Cystic Fibrosis. Royal Brompton Hospital. Endorsed by the Medicines Management Board of Royal Brompton \& Harefield NHS Foundation Trust.,The 6th edition. Available from: https://www.rbht.nhs.uk/our-services.

11. Smyth A.R., Scott C., Bojcin S., Bryon M. et al. (2014). European Cystic Fibrosis Society Standards of Care: Best Practice Guidelines. Journal of Cystic Fibrosis, 13, 23-42.

12. Leus P.A. (2011). Diagnosticheskoe znachenie gomeostaza slyuny v klinike terapevticheskoj stomatologii : ucheb.-metod. posobie [Diagnostic value of saliva homeostasis in the clinic of therapeutic dentistry: prac.-method. allowance]. Minsk: BGMU, 67 p.

13. Carev V.N., editor. (2013). Mikrobiologiya, virusologiya i immunologiya polosti rta : ucheb [Microbiology, virology and immunology of the oral cavity: studies]. Moscow: GEHOTAR-Media, 576 p.: il.

14. Aken B.L., Ayling S., Barrell D., Clarke L. et al. (2016). The Ensembl gene annotation system. doi: 10.1093/database/baw093.

15. Mattila K.J., Pussinen P.J., Paju S. (2005). Dental Infections And Cardiovascular Diseases: A Review. J. Periodontol, 76, 2085-2088. doi:10.1902/jop.2005.76.11-S.2085.

16. Rose M.C., Voynow J.A. (2006). Respiratory Tract Mucin Genes And Mucin Glycoproteins In Health And Disease. Physiol Rev, 86, 245-78.

17. Desseyn J-L., Rousseau K., Laine A. (1999). Fifty-nine bp Repeat Polymorphism In The Uncommon Intron 36 Of The Human Mucin Gene MUC5B. Electrophoresis, 20, 493-6.

Received: 17-Jul-2020

Accepted: 14-Jan-2020 